\title{
Recent and Historical Explorations of the Underwater Section of Cueva del Agua, Punta Los Ingleses, Mona Island (Puerto Rico), with a New Faunal Record ${ }^{1}$
}

\author{
Ángel M. Nieves-Rivera ${ }^{2}$, Jan P. Zegarra Vila ${ }^{3}$, Cielo E. Figuerola Hernández ${ }^{4}$, \\ Jaaziel E. García-Hernández ${ }^{5}$, and Nikolaos V. Schizas ${ }^{5}$
}

\begin{abstract}
In this study we provide a historical account of the underwater explorations conducted at Cueva del Agua, Punta Los Ingleses, Mona Island, Puerto Rico. We also present data from our own recent explorations and document a new zoological record: the unidentified estuarine demersal gastropod, similar to Polinices sp. The previously reported spinycheek sleeper fish Eleotris cf. pisonis was updated to E. cf. perniger. These specimens were photographed in situ. So far, only the native crustacean, Macrobrachium faustinum, had been studied in that cave, and by a few specialists, due to the danger, fragility and possible endemism that could exist in this cave system.

Resumen: En este estudio proporcionamos un recuento histórico de las exploraciones submarinas llevadas a cabo en Cueva del Agua, Punta Los Ingleses, Isla de Mona, Puerto Rico. También presentamos datos de nuestras propias exploraciones recientes y documentamos un nuevo registro zoológico: un gasterópodo demersal estuarino no identificado, similar a Polinices sp. El previamente informado pez dormilón espinoso Eleotris cf. pisonis fue actualizado a E. cf. perniger. Estos especímenes fueron fotografiados in situ. Hasta ahora, solo el crustáceo nativo Macrobrachium faustinum había sido estudiado en esa cueva, y por unos pocos especialistas, debido al peligro, fragilidad y posible endemismo que podría existir en este sistema cavernario.
\end{abstract}

Key Words: Biospeleology, caves, stygobiont, cave diving, Macrobrachium, Eleotris, subfossils, Isla de Mona, Caribbean

\section{Introduction}

Mona Island is an offshore island of $57 \mathrm{~km}^{2}$ in extension, located 75 $\mathrm{km}$ west of Puerto Rico and $65 \mathrm{~km}$ east of the Dominican Republic on the Mona Passage. Next to Mona $(\sim 6 \mathrm{~km})$ there is a smaller islet known as Monito Island, since 1986 both islands are part of a Natural Reserve

\footnotetext{
${ }^{1}$ Submitted on December 30, 2019. Accepted on February 15, 2019. Last revisions received on April 28, 2020.

${ }^{2}$ Félix Castillo Street 293, Mayagüez, Puerto Rico 00680-5201. E-mail: anieves740@yahoo.com, anievesster@gmail.com.

${ }^{3}$ P. O. Box 1777, Boquerón, Puerto Rico 00622. E-mail: jpzool@yahoo.com .

${ }^{4}$ HC 2 Box 27424, Cabo Rojo, Puerto Rico 00623. E-mail: cfiguerola@gmail.com .

${ }^{5}$ Marine Genomic Biodiversity Laboratory, Department of Marine Sciences, University of Puerto Rico, Mayagüez, Puerto Rico 00680. E-mails: jaaziel.garcia@upr.edu , nschizas@gmail.com , respectively.
}

DOI: 10.9784/LEB8(1)NievesRivera.01

Electronically available on April 30, 2020. Mailed on April 30, 2020. 
managed by the Puerto Rico Department of Natural and Environmental Resources (PRDNER). These islands have a complex history, which was extensively commented on by Cardona Bonet (1985), Wadsworth (1977, 2003), Nieves (2010), Cortés Zavala and Uribe Salas (2014), Sampson and Cooper (2015), Cooper et al. (2016), and their geology by Kaye (1959), Briggs and Seiders (1972), Cintrón et al. (1975), Frank et al. (1998), González et al. (1997), Mylroie and Mylroie (2007), Kambesis (2011a, b), Rodríguez Delgado et al. (2012), Lace et al. (2016), and Cardona Bonet (in press). The studies of vertebrate fossils by Williams (1952), Kaye (1959), Nieves-Rivera et al. (1995), Frank and Benson (1998), Nieves-Rivera and McFarlane (2001), Olson and Nieves-Rivera (2010), Olson (2015), NievesRivera (2019) highlighted the bones of some species of birds located in caves of the island.

The troglobiont ${ }^{6}$ and stygobiont ${ }^{7}$ fauna was previously studied by Peck and Kukalova-Peck (1981), and Smith and Weir (1999), respectively. The Natural Reserve consisting of Mona and Monito Islands is a living laboratory and has been called the "Galápagos of the West Indies" (Cardona Bonet 1985) due to its rich and unique flora and fauna biodiversity. Although these islands are particularly recognized for their peculiar karst conformations (flattened with a slight inclination, steep cliffs, and spectacular caves and caverns), their underwater caves - except for the reef caves of Las Carmelitas (Quinlan 1974) - have been poorly studied. Although the islands are a natural reserve, the main island is visited throughout the year by hunters, scientists, and park rangers. Some of these visitors are aware of the pool in Cueva del Agua in Punta Los Ingleses ${ }^{8}$, have bathed in its crystalline-blue, cool, and brackish waters, but only a few have been able to scuba dive in it. Although there is a peculiar biota in this cavernous portion, it has been scarcely studied, systematically. In this report, we documented novel wildlife records in the underwater section of Cueva del Agua and provided a historical account of the previous dives in which a record was kept.

The geology and cartography of Cueva del Agua was surveyed in Frank (1993), Martínez et al. (1995), Wicks and Troester (1998), Richards et al. (1998), Schmoll et al. (1999) (Figures 1-4), with some paleontological notes in Nieves-Rivera et al. (1995) and Schmoll et al. (1999). The biological information was included in Smith and Wier (1999) and Figuerola Hernández (2013). The photographic documentation was provided in Zegarra Vila (2013), and historical aspects in Cardona Bonet (2016). Cardona Bonet (2016) mentioned two similar caves, the Cueva del Agua or

\footnotetext{
${ }^{6}$ Troglobionts are organisms that live only in caves.

${ }^{7}$ Stygobionts are aquatic troglobionts.

${ }^{8}$ There is another Cueva del Agua by the Pozo del Portugués near Sardinera; unless otherwise indicated, in this paper we will refer to Cueva del Agua in Punta Los Ingleses.
} 
Del Pozo (between Punta Brava and Punta Los Ingleses, the one discussed in this paper) and Pozo or Pozo Salado ${ }^{9}$ (Figure 5A) between Playa Cocos and Punta Brava. Curiously, it is in the $16^{\text {th }}$ century that a traveler describes a cavity similar to the aquatic portion of Cueva del Agua: "The inhabitants are good people and very simple. His King came to see the captain's ships ... And he stayed two nights, then he took him ashore to see his orchards and his cave-shaped house and fountain called paradise, in a very deep rock hole, where he goes down per step, and said that the water from this source was cured of fevers" (Cardona Bonet 2019). The local fishermen knew about the existence of this aquatic portion of Cueva del Agua, in fact, a fisherman known as Pepe Barber ${ }^{10}$ is mentioned as connoisseur of the caves (Carlos Fronteras, personal communication, July 2017). It was between the 1940s and 1950s that José Barber Galiano (also known as Pepe, Figure 5B) was interviewed by the American arborist Frank H. Wadsworth during his trips to Mona as part of the book "Nuestra Isla del Tesoro Isla de la Mona" (Wadsworth 1977).

It is well known that "according to statements of commercial fishermen [Tres Hermanos ${ }^{11}$ (or Three Brothers)] who have been visiting the island since the 1940s, freshwater is available in some of the lowermost caves from Punta los Ingleses to Punta Caigo no Caigo. According to these accounts, freshwater could be obtained by carefully skimming the top of the water column in these water-filled caves" (González et al. 1997). When the first author of this publication visited the aquatic portion of this cave for the firs $t$ time, old wood that had been worked on in the past was found at the bottom and floating there. In the summer of 1990, it was the entomologist Héctor E. Quintero Vilella (Department of Biology, Inter-American University of Puerto Rico, San Germán Campus), who officially informed the PRDNER of the existence of this aquatic portion and posited to call the cave, or at least the underwater portion, as Quimanarí Cave (Nieves-Rivera 2012).

\footnotetext{
${ }^{9}$ We suspect this diveable cave is also known as Cueva del Agua II. Cardona Bonet (2019) referred to it as Playa del Pozo or Playa del Pozo Salado. There are stories that Puerto Real fishermen dove this cave years ago, probably Enrique Silva Rodríguez and Ramón Peña, discussed in the Underwater Explorations section.

${ }^{10}$ According to local fisherman Freddy Silva Rodríguez (personal communication, October $9^{\text {th }}, 2019$ ), the fisherman was his uncle José Barber Galiano (born May $26^{\text {th }}, 1880$ in Cabo Rojo and died May $9^{\text {th }}, 1965$ in Puerto Real, Cabo Rojo). Mr. Barber Galiano was the son of the Spanish citizen Esteban Barber [de Seda Mayor] and the Spanish Mariana Galiano [Lloret] and was married to María Rodríguez [Civil Registry of Cabo Rojo, Registry of Deaths 1965, images 1232-1233, certificate number 45 (www.familysearch.org)].

11 "Tres Hermanos", or Three Brothers, was a sloop with a single mast from Puerto Real, Cabo Rojo, that belonged to three brothers of the family Barber, hence the name. The Barbers are a well-known family of local fishermen and traders in Cabo Rojo.
} 


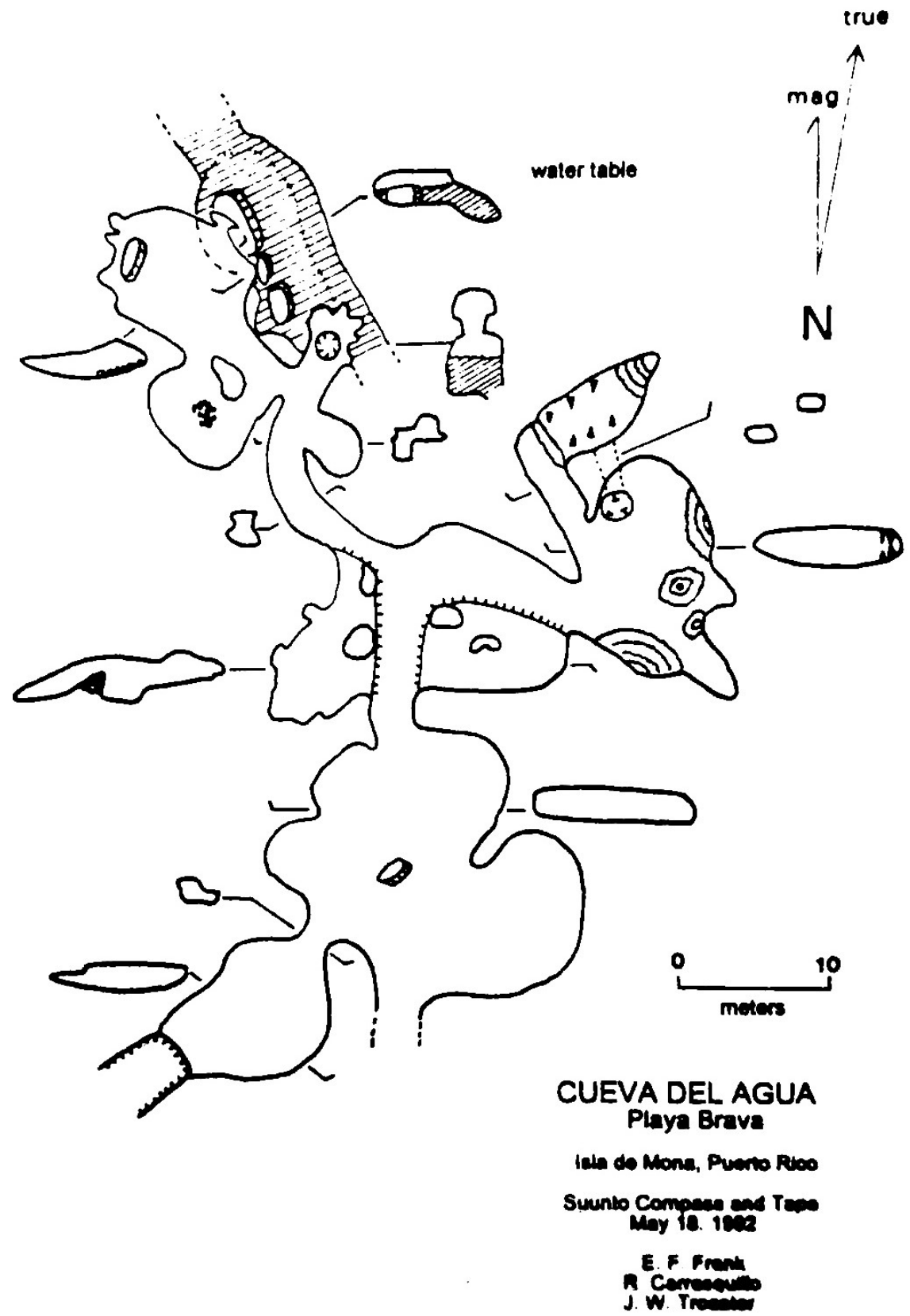

Figure 1. Cueva del Agua map at Playa Brava in Frank (1993), including a section of the underwater portion. 

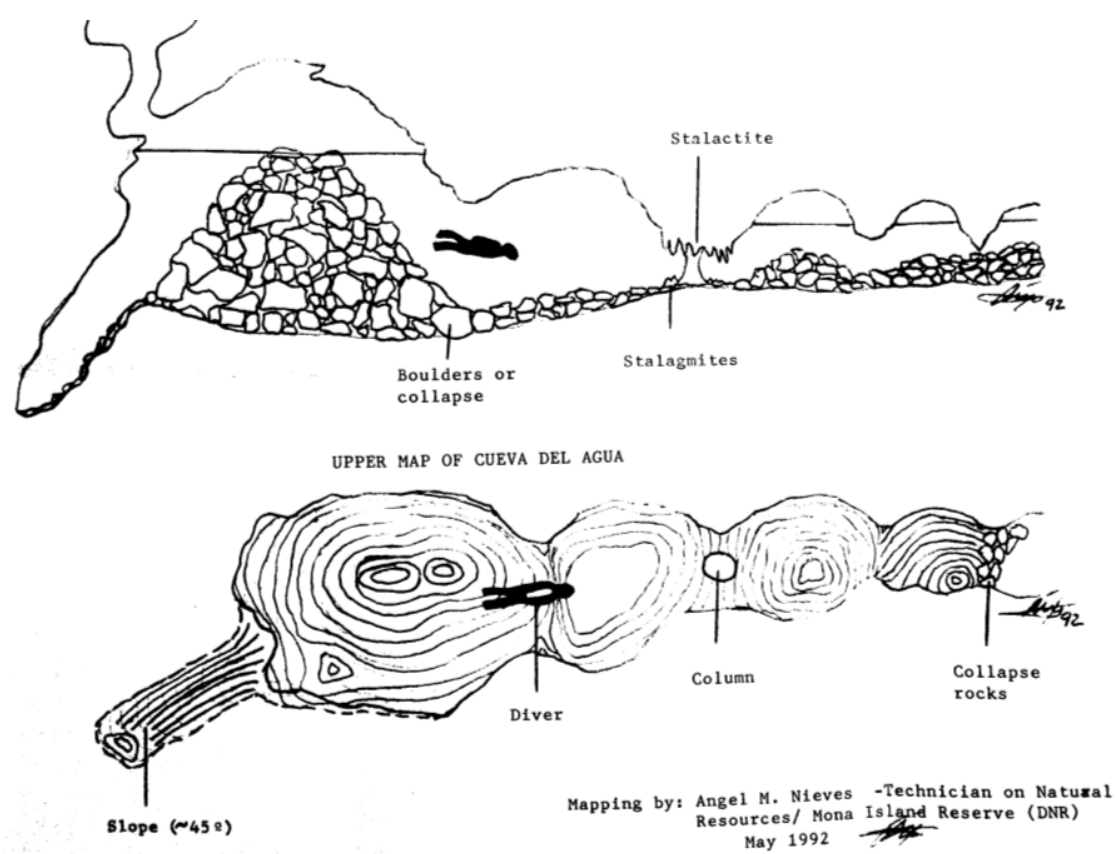

Figure 2. Sketch of the underwater portion of Cueva del Agua at Punta Los Ingleses. Prepared by ÁMNR in 1992 from the dive that took place in October 1991.

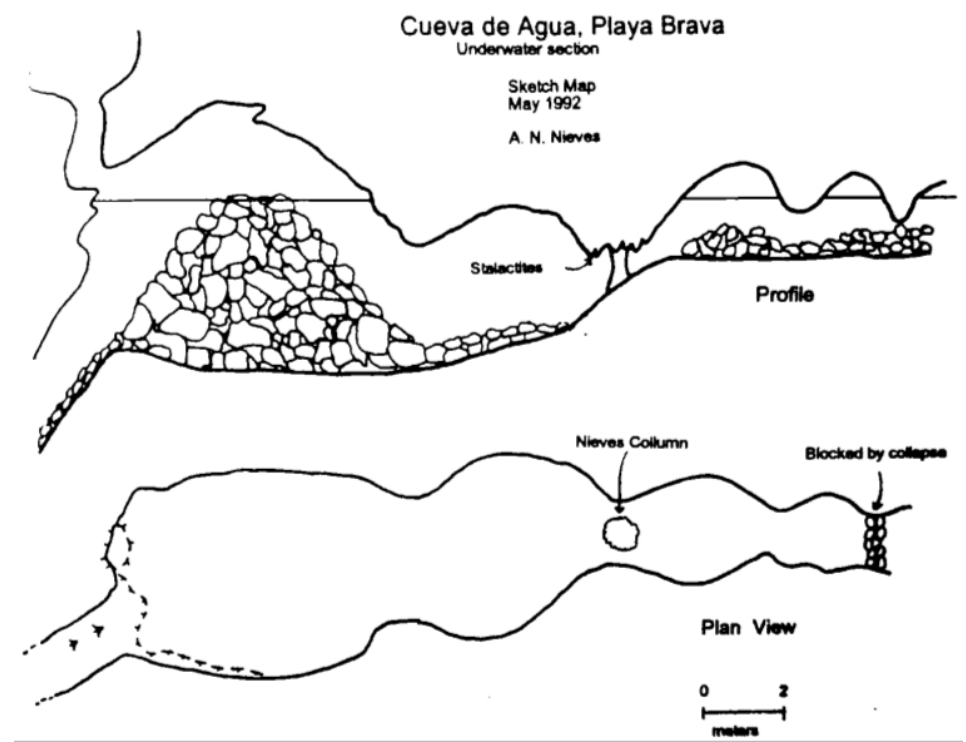

Figure 3. Sketch of the underwater portion of Cueva del Agua. Original sketch prepared by ÁMNR, modified in Frank (1993). Permission to reprint given by Edward F. Frank. 


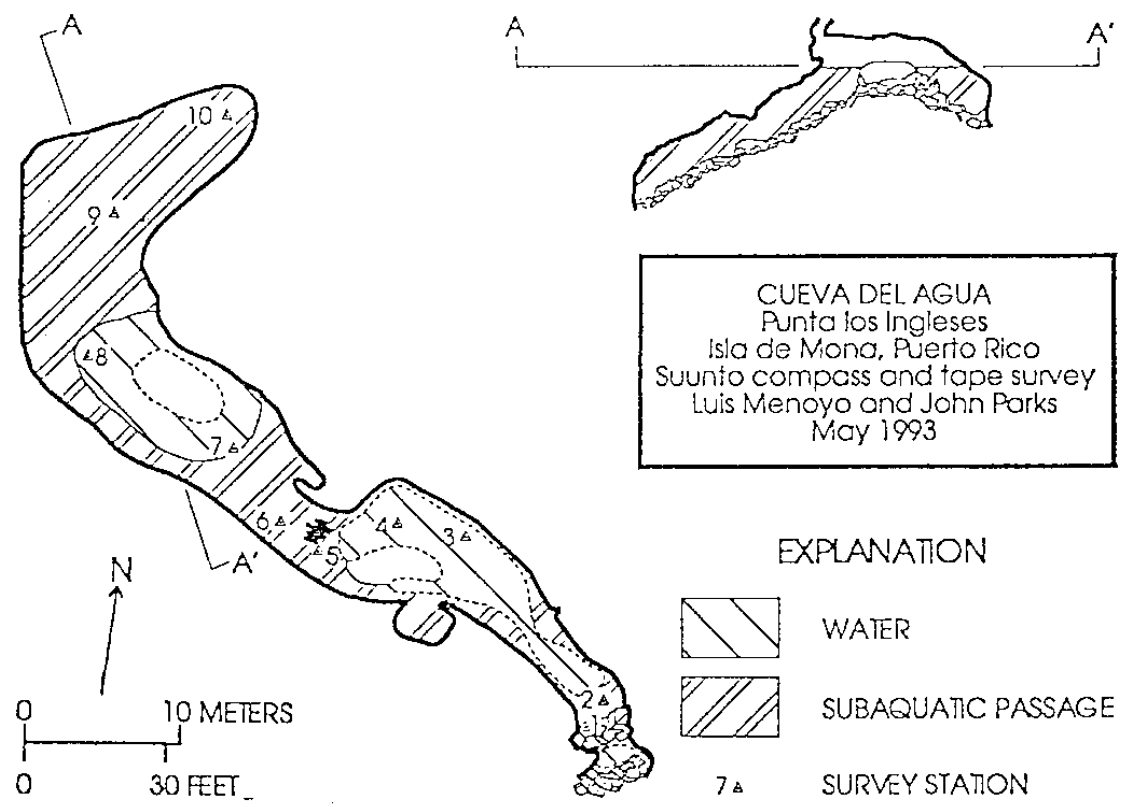

Figure 4. Updated map of the underwater portion of Cueva del Agua prepared by Menoyo and Parks (USGS) in 1993 (Wicks and Troester 1998). Permission to reprint given by John E. Parks.

Cueva del Agua is a cave found inland, not on the reef or underwater cliff, like those found in Veril de Carabinero and described by Cintrón et al. (1975). Beneath the plateau can be found in caves along the southern side of the island near Playa Los Ingleses, next to Punta Los Ingleses, the freshwaterseawater boundary of the freshwater lens. Cueva del Agua developed within reef-core facies of the Lirios Limestone and infilled by Quaternary reef rubble, composed mostly of the Elkhorn coral Acropora palmata (Lamark, 1816) (González et al. 1997). There is a 1.5-m-diameter hole in the cave floor which provides access to a $1.0-\mathrm{m}$-diameter pit that leads to a chamber developed within the Quaternary reef rubble and the Miocene reef-core facies (González et al. 1997). The chambers of Cueva del Agua are partially or completely filled with brackish water that shows a defined halocline. This cave extends at least $30 \mathrm{~m}$ north below the plateau, and an inclined tunnel extends south (seaward) for an indeterminate distance (González et al. 1997). There is a collapsed portion in the most distant section of the inclined tunnel which prevents determining the final distance of the tunnel (see Figures 2-4, 7B). An increase in salinity and turbidity in the water of the inclined tunnel can be easily detected (González et al. 1997). 


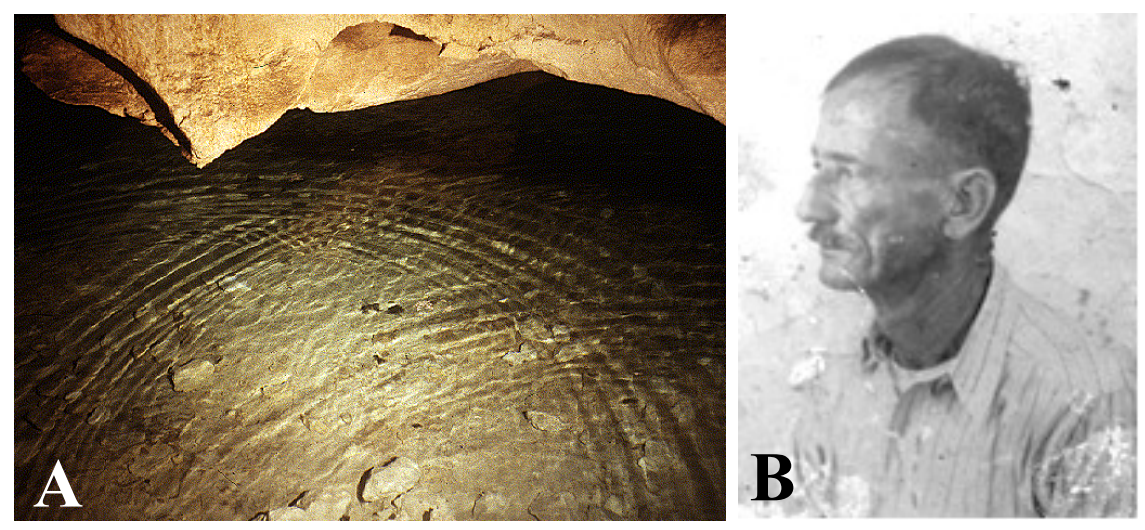

Figures 5A-B. A. Cueva del Agua II. Photo provided by John E. Parks. B. José "Pepe" Barber Galiano (1880-1965), Chin Ramírez Collection.

\section{Underwater Explorations}

There have been a number of undocumented recreational dives over the years to Cueva del Agua. The first known recreational dive was made by the fishermen Enrique A. Silva Rodríguez (Icky) and Ramón Peña (also known as Papi Peña, deceased), owner and former owner of the boats Jessica and Torpedo, respectively, during the late 1980s or early 1990s (Freddy Silva Rodríguez, personal communication, October $\left.9^{\text {th }}, 2019\right)$. The first scientific dive exploration to this cave was made by the management officer of PRDNER, Miguel A. Nieves Soto (also known as Tony Nieves), and the first author on October $14^{\text {th }}, 1991$ (Figure 2), and it was registered and documented in Frank (1993), and published by Nieves-Rivera et al. (1995) and González et al. (1997). Subsequently, in May 1993, a more concise map (Figure 4) was prepared by the USGS expeditions and by geologists of the University of Mississippi, among other institutions, and then published in Wicks and Troester (1998).

The following section summarizes the timeline and data gathered while diving in underwater caves (mainly Cueva del Agua) on the southeast of Mona Island, Puerto Rico:

October $14^{\text {th }}, 1991$ - Divers: First author and Miguel A. Nieves Soto Weather conditions: clear, sunny - Water conditions: transparent before diving, then silty - Depth: $10 \mathrm{~m}$ (32 ft) - Visibility: 0-10 m at all - Dive time: 10: 35-11: 00 hours - Bottom time: 25 min. - Observations: scientific diving for underwater cave exploration by PRDNER. There was no registered extant biota. Speleothems of underwater white calcite column and small air-filled chambers were discovered (Frank 1993). Subfossilized bones were collected in underwater passages (Nieves-Rivera et al. 1995). Boat: Tartaruga. Other people with us (but did not dive): Alberto Rodríguez and José Jiménez.

In this dive, an incursion was made to an underwater gallery in Cueva del Agua which produced some subfossil faunal remains reported in Nieves-Rivera 
et al. (1995) and are still being studied at the National Museum of Natural History (uncatalogued, NMNH) Smithsonian Institution, Washington, D.C. The remains included the bones from the Audubon's shearwater, Puffinus lherminieri Lesson, 1839, the Antillean ghost-faced bat, Mormoops blainvilii Leach, 1821, and a Mona Island ground iguana, Cyclura stejnegeri Barbour and Noble, 1916. The last two species probably became trapped and died in the pond (Nieves-Rivera et al. 1995). The Antillean ghost-faced bat, M. blainvilii, was also confirmed as still present in Mona Island (Gannon et al. 2005, Rodríguez-Durán and PadillaRodríguez 2010, Rodríguez-Durán and Christenson 2012). Zegarra Vila (2013: 50-51) showed two views of the floor of the chamber of Cueva del Agua covered mostly by bird bones, particularly of P. lherminieri (Figure 7A), although larger bones are noted (Figure 8A). During this dive, a sketch of this underwater portion was generated (Figure 2), and was sent to geologist Edward F. Frank, then an undergraduate student, at Mississippi State University (see Frank 1993). In his field notebook, the first author noted the halocline that other following expeditions have documented, but it was not until the publication of the photographic records made by Zegarra Vila (2013) that this physical phenomenon is clearly documented.

Summer 1993 - Divers: Dive Master Captain José Braulio (also known as Papo) and his aid Carlos Pacheco (The Dive Shop Puerto Rico, Mayagüez, Puerto Rico), the ecologist Félix López Arroyo and two other persons. This dive was exploratory but according to Braulio and López Arroyo, when descending to the aquatic portion, they noticed that some parts of the ceiling began to collapse, due to the softness of the limestone, and decided to abort the dive for safety reasons. This is a remarkable fact that must be considered when diving in certain portions of the cave and the potential danger should not be underestimated.

May 1993 - Divers: Luis Menoyo and John E. Parks (both of the United States Geological Survey [USGS], Guaynabo Offices, Puerto Rico; Figures 4, 6A). Although the connection to the sea is unnoticeable, perhaps due to small fissures, this connection to the sea and the tidal rise and fall has been corroborated during the study trips of the USGS). In the 1990s, 15 sensors were installed at intervals of one meter in Cueva del Agua to measure the electrical conductivity and temperature. The sensors have not yet been removed (Ronald T. Richards, personal communication to ÁMNR, June $\left.28^{\text {th }}, 2017\right)$. This information was corroborated by geologist John E. Parks, one of the divers of that USGS expedition in May 1993: "Indeed Luis and I dove Cueva del Agua in the early $1990 \mathrm{~s}$. We also installed conductivity probes at $1.0 \mathrm{ft}[30 \mathrm{~cm}]$ interval depths to determine if there was a tidal influence on the halocline and indeed there was. It was several hours delayed from ocean tides, but the connection was clear. This movement of the halocline is likely a contributing factor to faster dissolution in the zones of fluctuation" (John E. Parks, personal communication to ÁMNR, June $22,2018)$. 
August 2003 - Divers: geologist Wilson R. Ramírez Martínez (Department of Geology, University of Puerto Rico, Mayagüez), physician Dr. R. Maíz from Cabo Rojo and the French diver Denis Bourret of Golden Arrow Technical Dive Center, Dominican Republic. Photographs of the expedition exist (Figures 6B-C); this as part of Ramírez Martínez studies in sedimentary petrography especially in dolomitization in brackish waters produced by the mixing of meteoric and marine waters (Wilson R. Ramírez Martínez, personal communication to ÁMNR, November $\left.26^{\text {th }}, 2019\right)$.

May 26 ${ }^{\text {th }}, 2013$ - Divers: JPZV and Esdras Salas (Figure 8B). They went to Mona with a group of divers and stayed at Playa de Pájaros. The captain's assistant took them in a small motored inflatable dinghy and once they arrived at the little beach located almost in front of the cave, they were careful with the waves. Once on the shore both divers put on the diving equipment as if they were going to dive and with the diving boots, they walked very carefully until they reached the drop to the water portion of the cave. It was a short but intense walk by the weight of the equipment and the camera. Carefully, they lowered the equipment into the water and then themselves (JPZV and E. Salas, the leader of the team). Only two divers were in the cave as three divers would seem to have been uncomfortable. They also went in without diving fins because they could stir the fine sediment at the bottom of the cave and cloud visibility. With full tanks and two lights per diver, they went in to explore without leaving the guide line out of sight. By adjusting buoyancy and swimming very slowly, they moved on carefully. The first chamber seems to be the widest and the formations are impressive. It is noted that several collapses have occurred due to the size of the rocks at the bottom. JPZV remembers that there were at least one or two additional chambers that allow divers to emerge and breathe fresh air, as the first author did in 1991. The section was not exceptionally long. The end of the tunnel finishes in what looks like another rock collapse (Figure 7B). Upon return, the water was not as clear because of the sediment suspension making subsequent dives dangerous due to the deterioration of visibility. Once back to the beginning, they explored the crack located below the aquatic section facing north (see figure 4, survey stations 8-10). There is also a line but a shorter one. Interestingly, the halocline is noticeable because the water looks out of focus as the first author saw in 1991. In that "crack" there were rocks colored with some reddish brown to a golden yellow tone as if some chemical reactions were happening there different from those occurring in the rest of the cave. JPZV took a few photos including some of the bones possibly of shearwaters or bats but did not see any signs of macrolife.

March 6 ${ }^{\text {th }}, 2015$ - Snorkeling: JPZV and CEFH. JPZV and CEFH went to Mona to help American herpetologist Peter Tolson with his work on the Mona Island boa, Chilabothrus monensis (Zenneck, 1898). The purpose of 
this snorkeling trip was to try to photograph the shrimp, Macrobrachium faustinum de Saussure, 1857. They used a small mesh bag with fish food to attract the previously documented species of shrimp. According to recommendations by CEFH, one must stay still for a while and keep calm to see them. To their surprise, a fish appeared first, which JPZV could photograph it well as it did not move much. JPZV notes: "Luckily, a shrimp later appeared. They are almost transparent. With a lot of patience and slow movements, I got a few photos, but not many. I kept looking around and that was when I noticed the snail, which I photographed it as well."
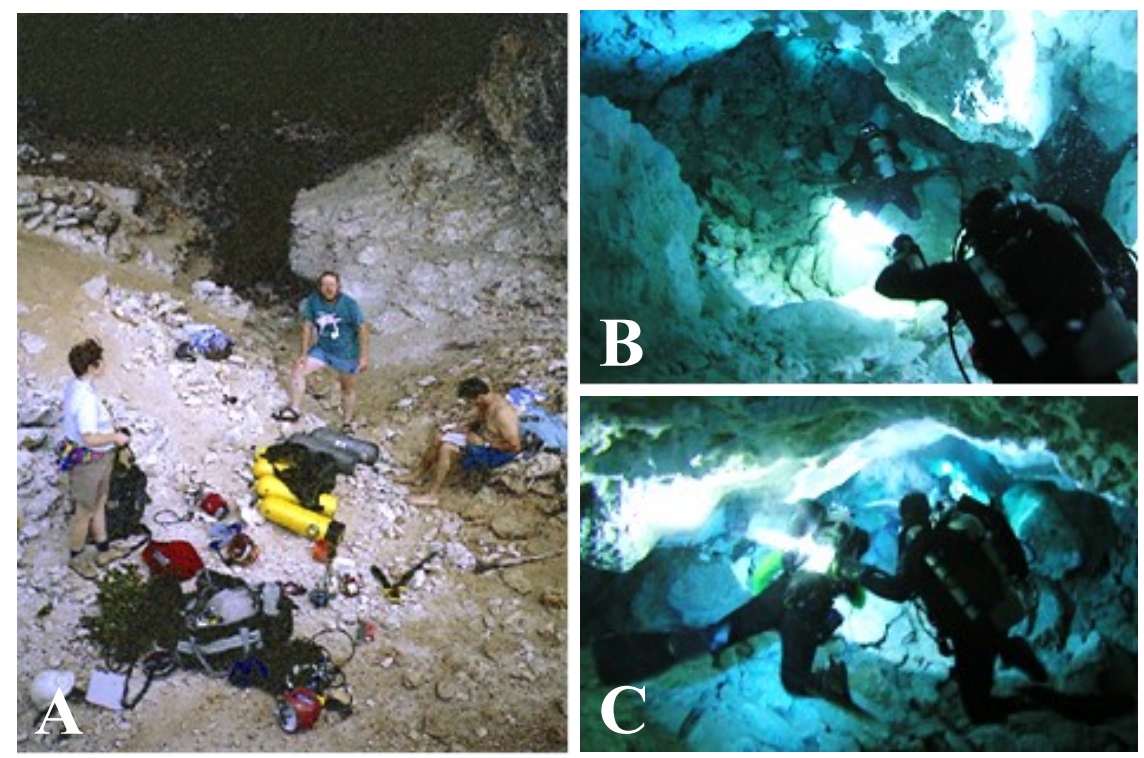

Figures 6A-C. A. Preparing for the dive of the USGS expedition in 1993. Permission by John E. Parks. B-C. Dive in Cueva del Agua in August 2003. Permission by Wilson R. Ramírez.

June 14 ${ }^{\text {th }}, 2016$ - Diver: ÁMNR; Félix López Arroyo (snorkeling); collaborators: Walter Á. Cardona Bonet, and Alberto López Rodríguez Weather conditions: partially cloudy, slightly windy - Water conditions: transparent before immersion, then silty - Depth: $6.1 \mathrm{~m}$ (20 feet) - Visibility: 0-10 $\mathrm{m}$ to none - Water temperature: $70^{\circ} \mathrm{F}\left(21^{\circ} \mathrm{C}\right)$ - Dive time: 11:1512:22 hours - Bottom time: $65 \mathrm{~min}$. - Observations: scientific documentation of wildlife remains (subfossil bones) such as those of birds (most of them $P$. lherminieri, a few of Caracara [Polyborus] aff. creightoni Brodkorb, 1959) and the lower jaw of the Puerto Rican hutia, Isolobodon portoricensis Allen, 1916. The diver and collaborators transported a single tank on foot, crossing the "razor's edge" (Punta Los Ingleses) from Playa de Pájaros to Cueva del 
Agua. Other people in the expedition that entered the water, but did not dive, were the Eagle Scout Alberto López Rodríguez, son of Félix López Arroyo, and out of the water (in case of emergency) was the maritime historian and genealogist Walter Á. Cardona Bonet. During the dive, no fins were used to avoid siltation and reduction of visibility.
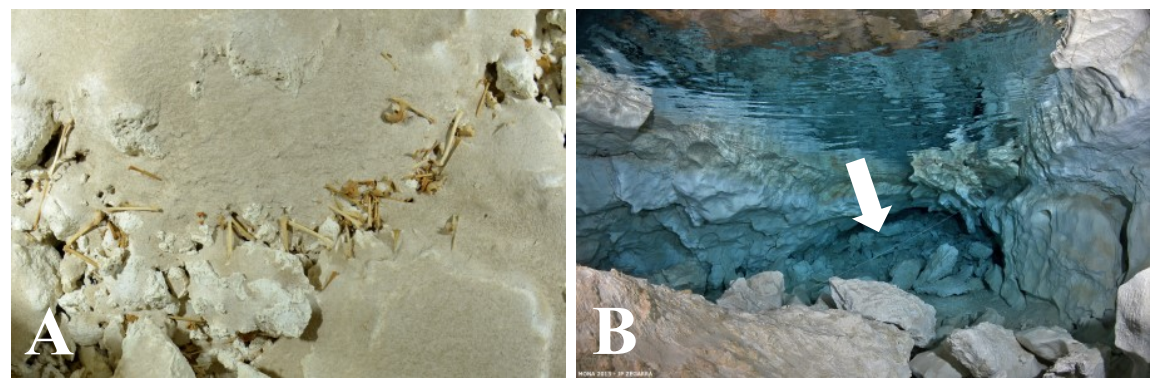

Figure 7. Underwater views of Cueva del Agua. A. Audubon's shearwater bones, Puffinus lherminieri, on the floor of Cueva del Agua. B. Southeastern view towards the collapsed section of Cueva del Agua, guide line visible (arrow).

The exploration was conducted to taxonomically document the faunal remains of fossil and subfossil birds, as well as the invertebrate biota, previously reported in this part of the cave. As in the first dive in 1991, the first author did not see the M. faustinum noted by Smith and Wier (1999) in their studies about invertebrates on the island (Nieves-Rivera and Williams 2003) due to the translucent nature of their bodies. Macrobrachium faustinum was trapped in the subfossil samples when sediment was collected with water, so the bones were not exposed to the air immediately and cracked. The shrimp was preserved in $70 \%$ ethanol and was used in this study.

Although it was a scientific dive, all evidence was documented in a photographic form and the recovered bones were sent to paleornithologist Storrs L. Olson (Emeritus Zoologist of NMNH, Smithsonian Institute in Washington, D.C.). This research is in progress, showing some preliminary results such as a record of a single well-preserved notarium of a caracara, C. aff. creightoni, in Cueva del Agua. The caracara remains were originally collected from the material that was published in Nieves-Rivera et al. (1995). This species was not mentioned in this publication; Olson himself identified it and subsequently mentioned it in another publication (Olson 2008).

October 14 ${ }^{\text {th }}, 2016$ - Divers: JPZV and Esdras Salas. On another dive trip with E. Salas, both divers returned to Cueva del Agua. This time with smaller dive tanks, apparently 63 cubic feet instead of the traditional size of 80 cubic feet. Such a large tank is not needed for that cave. JPZV and E. 
Salas followed the same procedure in the cave but this time the group arrived by kayak. The guide lines remained intact. JPZV remembers "a slight occasional itching probably from the sediment so fine in contact with the skin similar to fiberglass itching but milder. We did not see any other forms of life."
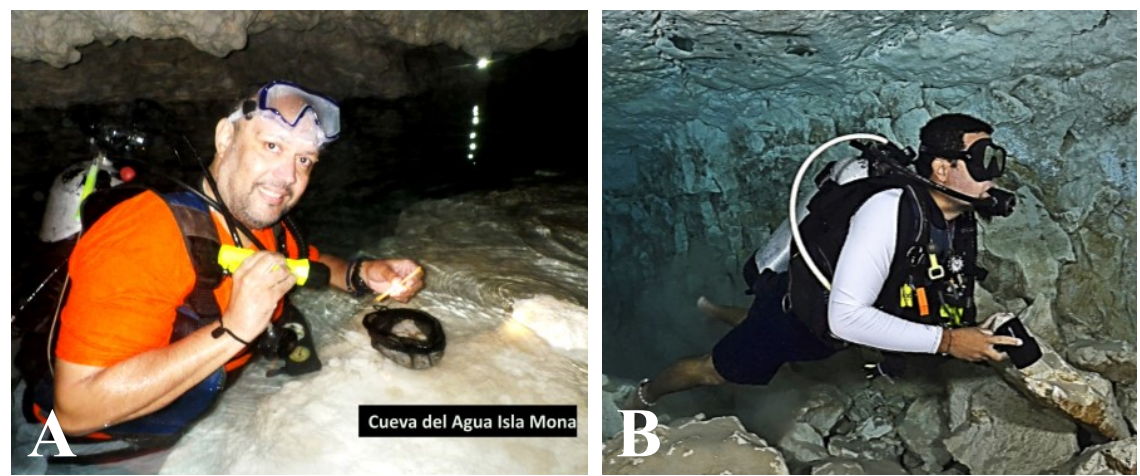

Figure 8A-B. Hard at work in Cueva del Agua. A. First author. B. Esdras Salas.

Extant fauna. Although an unrelated stygobitic shrimp, the Mona cave shrimp, Typhlatya monae Chace, 1954, was originally reported from Mona Island's caves (Chace 1954, Botello et al. 2013) it has not been documented in the underwater section of Cueva del Agua, although it was originally collected from a well next to Sardinera believed to be Pozo del Portugués on the western side of the island. There are other species of crustaceans that live in environments such as sinks and openings in caves that function as phytotelma (defined as a small cavity or container carrying water in a land plant, for example bromeliads) that could be reservoirs of biota that could become part of the cave fauna, if the opportunity develops. Some invertebrate specimens collected in phytotelmata on Mona Island were reported in Nieves-Rivera and Williams (2003).

So far, only the native crustacean, M. faustinum (Figures 9A-B) has been studied in that cave by a few specialists because of the danger, fragility and possible endemism that could exist in this cave system. Zoologists from the University of Massachusetts first documented the presence of this decapod in the cave system (Smith and Wier 1999). It is interesting to note that this shrimp is commonly found in ravines and rivers of Puerto Rico and other Caribbean regions. In Puerto Rico it is known as zurdito or camarón bocú (Pérez-Reyes et al. 2013), and as Caribbean long arm shrimp elsewhere. The common name 'Popeye' is also widely used in Puerto Rico for the males of several other species, including Atya scabra (Leach, 1816) (Carlos J. Santos-Flores, personal communication, 2020). According to the research of Smith and Wier (1999) and Figuerola Hernández (2013), it is 
possible that in past times, Mona Island was able to retain bodies of freshwater for a prolonged time on its surface and that these organisms could migrate through the rocks and their exchange of freshwater and they may have reached these water lenses such as Cueva del Agua. As is well known in the biology of M. faustinum and other species of Macrobrachium, these organisms have an amphidromous life cycle, which requires a stage of their life in fresh or brackish water, and spending time in seawater completing body development. Perhaps in this case, the larvae are hatched in brackish water, can then move to more saline areas, and may even migrate depending on the halocline. More detailed studies on the life history of these crustaceans need to be done.

Considering that these organisms are stygobionts, it is logical to think that they have a slow metabolism as a means of survival and low oxygenation as food is scarce. Obviously, the brackish water of Cueva del Agua does not prevent or affect the life cycle of M. faustinum (Figuerola Hernández 2013), because brackish water goes from almost freshwater to sub-saline. There are cracks in the rocks, so shrimps can easily migrate back and forth to the ocean. There is also a very remote possibility that the presence of these shrimps is due to vicariance, a relict of a population in which individuals have arrived through isolated events or the dynamics of recruitment and population genetics may have changed. It is possible that they feed on detritus and macro- and microorganisms, as well as cannibalism. These are considered as possibilities that contribute to sustenance in the trophic chain in this cave and similar systems. According to the studies by Smith and Wier (1999), Figuerola Hernández (2013), and by the limnologist colleague Carlos J. Santos-Flores (personal communication, 2019; based on the taxonomic key by Pérez-Reyes et al. 2013), we understand that it is a variety of M. faustinum, but the chelae are slightly smaller than published descriptions and the rostrum is somewhat longer, resembling that of other species of Macrobrachium species. However, the dimensions of both characters (chelae and rostrum) are affected by age, sex, growth rate, reproductive stage, and presence of predators, among others. The specimen of M. faustinum was photographed in figures 9A-B; the whole specimen (Figure 9A) and a close up of the rostrum (Figure 9B). Other studies in progress, based on molecular sequencing of mitochondrial markers, are being carried out by some of us (NVS and his graduate student JEGH) at the Marine Genomic Biodiversity Laboratory located in Magueyes Island Marine Laboratories (Department of Marine Sciences, University of Puerto Rico, Mayagüez). The purpose of that ongoing study is to corroborate the identity and phylogeny of M. faustinum, and results will be presented in a subsequent publication. Preliminarily, it was determined that this Macrobrachium is a species whose sequence is not included in the GenBank records, and further studies are being carried out. 


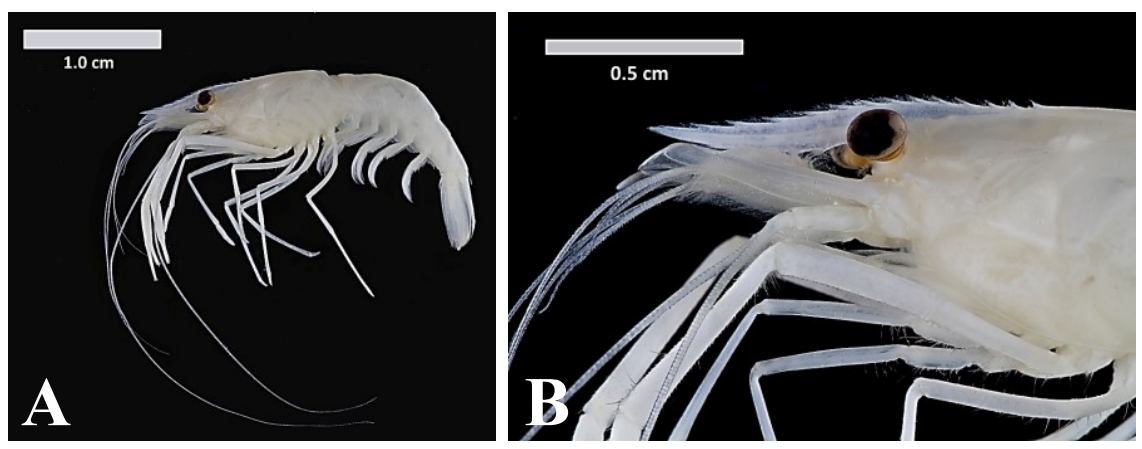

Figures 9A-B. A. Overall lateral view of Macrobrachium faustinum, also known as Popeye. B. Closeup of anterior portion of Figure 9A. Photos courtesy José R. Almodóvar.
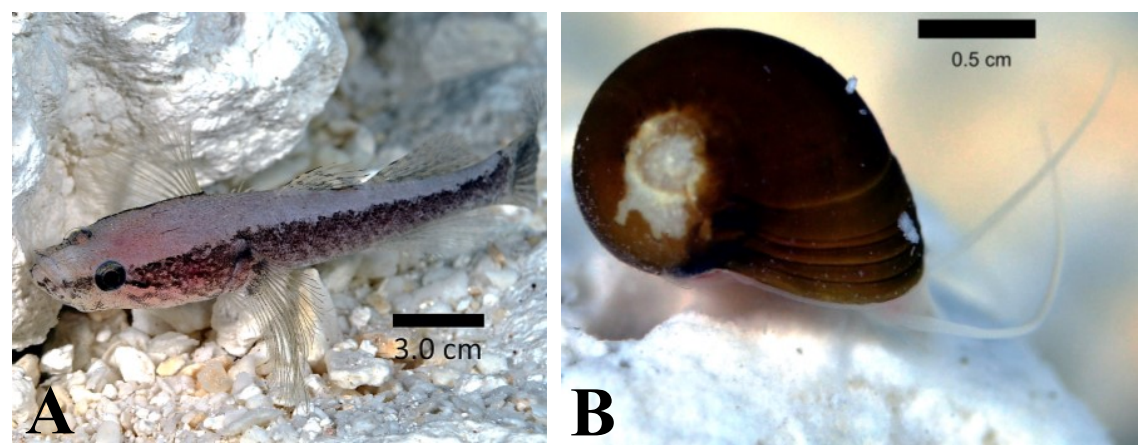

Figures 10A-B. A. Spinycheek sleeper, Eleotris cf. perniger. B. Unidentified estuarine gastropod, possibly a member of the family Naticidae. Photos by co-author JPZV.

Smith and Wier (1999) commented on the presence in Cueva del Agua of a freshwater fish native to this subtropical region. Herein, the presence of the smallscaled spinycheek sleeper, Eleotris cf. perniger (Eleotridae: Perciformes) is recorded (Figure 10A). Although it was previously reported in Smith and Weir (1999) and Figuerola Hernández (2013) as the spiny-cheek sleeper Eleotris cf. pisonis $^{12}$ (Gmelin, 1789), it is already reported from marine habitats in Mona Island (CCUSAF 1973). Species of Eleotris can live in a salinity range of 0 to 19 ppm, in some cases up to $36.6 \mathrm{ppm}$, and they feed on larvae and pupae of aquatic

\footnotetext{
12 "The records of Eleotris pisonis for Puerto Rico and other Greater Antilles refer mostly to Eleotris perniger. Since 1990s, Eleotris pisonis is considered as a species not found in Central America. Both species are similar and were long confused. On the other hand, two specimens that resemble the Eleotris amblyopsis (Cope, 1871) species, known in English as large-scaled spinycheek sleeper, were collected a couple of years ago on the island of Montserrat. Eleotris perniger and E. amblyopis are also similar and, thus, can be easily confused too." (Carlos J. Santos-Flores, personal communication, 2020).
} 
dipterans, crustaceans such as crabs and shrimps, and small fishes. The diet changes according to sexual maturity and season.

In addition, an unidentified estuarine gastropod was documented (Figure 10B). This gastropod has a light to dark brown shell, with a slightly elevated dextral, smooth opening, the ventral foot is transparent to slightly whitish and the antennae or tentacles long and slightly pointed. It appears to be a demersal gastropod which is slightly similar to Polinices sp. (Naticidae), but data are still missing, and it is necessary to collect specimens to confirm the species identification.

The presence of these organisms supports the connection of the groundwater with the seawater, as demonstrated by the evidence of geophysical studies such as Martínez et al. (1995) and Richards et al. (1998).

Extinct fauna. To date, there are more concrete data regarding the prehistoric fauna that inhabited Cueva del Agua than when the first author started to collect the first bones from the cave. Previous to that first exploration, there appears to be no evidence of fossil or subfossil collections carried out specifically in Cueva del Agua, not even those reported in the classic scientific works, and none has been collected from the underwater section. Some of these remains are currently under scrutiny to corroborate their identity and proper taxonomy. Kaye (1959) found some interesting fossil and subfossil bones in cave deposits, such as those of the marine bird P. lherminieri and the hutia I. portoricensis. Subsequently, both species have been independently collected from Cueva del Agua.

According to the evidence we have found, the underwater section of Cueva del Agua is one of the areas of Mona Island that was not significantly altered by the mining action. The absence of mining destruction in this part of the cave renders it as an extremely important study site to understand the paleobiogeography in the Greater Antilles and its islets: the Audubon's shearwater bones found on the bottom of the underwater portion of the cave is one example. The Audubon's shearwaters, called "patitas" by local fishermen according to Erdman (1967), are circumtropical pelagic birds and have been reported in the literature as follows: "observed by Barnés sometimes on the cliffs of northern Mona Island" (see report by Barnés 1946, Rolle 1961). According to paleontological studies of this species in the West Indian arch, it has been reported in Quaternary deposits (about 11,180 \pm 105 years before the present), although Panuska et al. (1998) extended the minimum age of this species to 2 orders of magnitude. Although $P$. lherminieri used Mona's caves extensively as nesting sites and it is understood that the presence of $P$. lherminieri in Mona dates from 1.8-2.0 Ma (Panuska et al. 1998), it is believed that the population was excised or quasi-excised from the island, perhaps due to predation by rats, Rattus rattus (Linnaeus, 1758), by feral cats, Felix catus Linnaeus, 1758, and possibly by humans. The latter is demonstrated by the abundant remains of mixed charcoal and $P$. lherminieri bones deposited in improvised anthropogenic kitchen middens, one of those ${ }^{14} \mathrm{C}$ radiocarbon dated by Frank (1998) in calendared dates ranging 
from 1480 to $1655 \mathrm{AD}$ in Cueva Negra. However, it is reported that this species is still present in Mona, but with only a few specimens left on the cliffs of Mona. In the report by Pérez-Rivera and Bonilla (1983) is mentioned: "The last one who reported 'pamperos' [plural in Spanish for Audubon's shearwater] in Mona turns out to be Erdman (1967) in March 1960. On May 30 ${ }^{\text {th }}$, 1981, we observed one of these birds on the north coast of Mona flying over the area near the cliff. It is believed that in previous years the 'pampero' nested in Mona and the date of our observation, gives rise to speculation on this particular in present times." These reports of Audubon's shearwaters in Mona are scattered in many publications or internet reports, but for the benefit of the readers we included a few, specifically Barnés (1946), Erdman (1967), and Pérez-Rivera and Bonilla (1983), a photo of a single individual by Mike Morel in Anonymous (2013). Moreover, various shearwaters are known to nest in the northern cliffs of Mona Island (CEFH, personal observation, 2017).

The prehistoric fauna of Cueva del Agua resembles that of a flooded cave in Barbers Point, O'ahu (Hawai'i) in which there are skeletons of crows Corvus spp. -although in Cueva del Agua there are mostly bones of P. Iherminieri - that lay in the place where they died when the cave was dry, then the sea level increased in the last thousand years and the cave was filled with freshwater (Storrs L. Olson, personal communication to ÁMNR 2018). When there are cracks and porosity, being not too far from the coast, seawater infiltrates, generating brackish water. Thus, the fossil vertebrates of Cueva del Agua died in the cave during the last interglacial period (MIS 5e) or the Riss-Würm Interglacier, or equivalent to $128,000-116,000 \mathrm{ybp}$, which was much warmer and wetter than the climate of the Holocene. This Interglaciar Riss-Würm could be $2^{\circ} \mathrm{C}$ hotter than the Holocene due to the extension of large Interglaciar Riss-Würm wooded areas which reached a much greater and northern extension than currently believed (Rovere et al. 2016).

The deposits in the caves are places of great importance because faunal remains are usually preserved and accumulated over time. These deposits have contributed greatly to our knowledge of life in recent times but particularly in our remote past. It is well known that where there are large populations of bats and birds, they can adversely affect the preservation of bone remains because excrements, urine, microbiota, and environmental factors, among others, literally digest or recycle these remains. An additional consideration is the invertebrate populations that consume all available food. This perhaps explains the absence of conspicuous amount of bones in many Mona Island caves, unless they belong to large and recent organisms such as pigs and goats. It is remarkable to highlight the amount of bone remains covered with calcite; this phenomenon is common in many of Mona's caves, (e.g., Cueva Lirios, Cueva del Alemán, Cueva Losetas, Cueva Esqueleto, Cueva Diamante). Biospeleological and paleontological exploration in Mona Island is technically just beginning, with many surprising findings sure to be recorded. 


\section{Acknowledgments}

We thank the paleornithologist Storrs L. Olson (NMNH, Smithsonian Institute, Washington, District of Columbia, USA) for the identification of the fossil material and the economic support for this research, as well as the maritime historian and genealogist Walter A. Cardona Bonet. Paleontologist Renato Rímoli (Dominican Republic) also confirmed the identification of specimens; we also thank Félix López Arroyo, Alberto López Rodríguez and Miguel A. Nieves Soto for the logistics of the trip. The photographs of Macrobrachium faustinum were taken by the photographer José R. Almodóvar (Department of Biology, University of Puerto Rico, Mayagüez, Puerto Rico). We also thank John E. Parks, Wilson R. Ramírez and fishermen from Puerto Real for their historical observations and comments. The subfossil specimens studied in the survey were gathered under the collection permit DRN-95-13 to ÁMNR and by Storrs L. Olson authorization letter of March 2008 and signed by PRDNER Secretary at the time Javier Vélez Arocho. Thanks to reviewers, especially Carlos J. Santos-Flores (Department of Biology, University of Puerto Rico, Mayagüez) and Steve L. Stephenson (Department of Biological Sciences, University of Arkansas, Fayetteville), and several other colleagues who remained anonymous for their comments, support, and improvements of this manuscript.

\section{Literature Cited}

Anonymous. 2013. Puerto Rico eBird: Birdwatchers travel on sea to find pelagic birds: Audubon's shearwater (Puffinus lherminieri). Photo courtesy of Mike Morel (November $1^{\text {st }}, 2013$ ). http://ebird.org/pr/news/birdwatchers-travel-on-sea-to-find-pelagic-birds (Accessed in World Wide Web on 23 December 2019).

Barnés, Jr., V. 1946. Las aves de la Isla de Mona. Revista de Agricultura de Puerto Rico 37(2):105113.

Botello, A., T. M. Iliffe, F. Álvarez, C. Juan, J. Pons and D. Jaume. 2013. Historical biogeography and phylogeny of Typhlatya cave shrimps (Decapoda: Atydae) based on mitochondrial and nuclear data. Journal of Biogeography 40:594-607. https://doi.org/10.1111/jbi.12020

Briggs, R. P. and V. M. Seiders. 1972. Geologic map of the Isla de Mona quadrangle, Puerto Rico. Miscellaneous Geological Investigations, U.S. Geological Survey. Map I-718.

Cardona Bonet, W. Á. 1985. Islotes de Borinquen (Amona, Abey, Piñas, Sikeo y otros): Notas para Su Historia. Model Offspring, San Juan, Puerto Rico. 127 pp.

Cardona Bonet, W. Á. 2016. Reconocimiento histórico-arqueológico de Isla de Mona (1994). Published by the author, Bayamón, Puerto Rico. 192 pp. [www.lulu.com/shop/Walter-acardona-bonet/estudio-hist $\%$ c3\%b3rico-arqueol $\%$ c3\%b3gico-de-isla-demona/paperback/product-23247363.html].

Cardona Bonet, W. Á. 2019. Las cuevas de Isla de Mona en la ruta trasatlántica del siglo dieciséis. In, Federación Espeleológica de Puerto Rico (FEPUR, Editors), II Simposio Espeleológico de la FEPUR: "Las maravillas del karso: Retos y Perspectivas" (August 24 ${ }^{\text {th }}$ ), Oral presentation in this symposium. Inter American University of Puerto Rico, Bayamón Campus.

Cardona Bonet, W. Á. (in press). Los caciques de la Mona. Revista Hereditas [Sociedad Puertorriqueña de Genealogía].

Chace, F. A. 1954. Two new subterranean shrimps (Decapoda: Caridea) from Florida and the West Indies, with a revised key to the American species. Journal of the Washington Academy of Sciences 44:318-324.

Cintrón, G., J. Thurston, J. Williams, and F. MacKenzie. 1975. Características de la plataforma insular de Isla de Mona. pp. 69-91. In, Departamento de Recursos Naturales de Puerto Rico (Editors) II Simposio de los Recursos Naturales. Programa de la Zona Costanera. Departamento de Recursos Naturales de Puerto Rico, San Juan, Puerto Rico. 280 pp.

CCUSAF (Commander in Chief U.S. Atlantic Fleet). 1973. Draft environmental impact statement. U.S. Navy, Atlantic Fleet Integrated Weapons Training Ranges (Culebra Study). Report by Tippetts-Abbett-McCarthy-Stratton Engineers and Consultants, New York. Pp. 4-26.

Cooper, J., A. V. M. Sampson, M. A. Nieves, M. J. Lace, J. Caamaño-Dones, C. Cartwright, P. N. Kambesis, and L. del Olmo Frese. 2016. The 'Mona Chronicle': The archaeology of early religious encounter in the New World. Antiquity 90:1054-1071. https://doi.org/10.15184/aqy.2016.103 
Cortés Zavala, M. T. and J. A. Uribe Salas. 2014. Ciencia y economía del guano: La Isla Mona de Puerto Rico, siglo XIX. Memorias: Revista Digital de Historia y Arqueología desde el Caribe Colombiano 11(22):81-106. https://doi.org/10.14482/memor.22.5948

Erdman, D. 1967. Sea bird in relation to game fish schools off Puerto Rico and the Virgin Islands. Caribbean Journal of Science 7(1-2):79-85.

Figuerola Hernández, C. E. 2013. Popeye: El curioso caso del camarón que llegó a Cueva del Agua. Espeleorevista Puerto Rico 8:12-18 [https://issuu.com/espeleorevista/docs/espeleorevista_8].

Frank, E. F. 1993. Aspects of karst development and speleogenesis Isla de Mona, Puerto Rico: An analogue for Pleistocene speleogenesis in the Bahamas. M.Sc. Thesis, Mississippi State University, Mississippi. 288 pp.

Frank, E. F. 1998. A radiocarbon date of $380 \pm$ BP for a Taino site, Cueva Negra, Isla de Mona, Puerto Rico. Journal of Caves and Karst Studies 60(2):101-102.

Frank, E. F. and R. Benson. 1998. Vertebrate paleontology of Isla de Mona, Puerto Rico. Journal of Caves and Karst Studies 60 (2):103-106.

Frank, E. F., C. Wicks, J. Mylroie, J. Troester, E. Calvin Alexander, Jr. and J. Carew. 1998. Geology of Isla de Mona, Puerto Rico. Journal of Caves and Karst Studies 60(2):69-72.

Gannon, M. R., A. Kurta, A. Rodríguez-Durán, and M. R. Willig. 2005. Bats of Puerto Rico: An Island Focus and a Caribbean Perspective. Texas Tech University Press. Lubbock, Texas, USA. 239 pp.

González, L. A., H. M. Ruiz, B. E. Taggart, A. F. Budd, and V. Monell. 1997. Chapter 9: Geology of Isla de Mona, Puerto Rico. In, Varcher, H. L. and T. M. Quinn (Editors) Geology and Hydrology of Carbonate Islands: Developments in Sedimentology 54:327-358. [Elsevier Science B.V.] https://doi.org/10.1016/S0070-4571(04)80031-1

Kambesis, P. N. 2011 a. Documenting the caves of Isla de Mona. EspeleoRevista Puerto Rico 4:4-7.

Kambesis, P. N. 2011b. Isla de Mona expedition - June 2011. EspeleoRevista Puerto Rico 5:16-17.

Kaye, C. A. 1959. Geology of Isla Mona, Puerto Rico, and notes on the age of Mona Passage. U.S. Geological Survey Professional Paper 317-C. Washington, District of Columbia, USA. 49 pp.

Lace, M. J., P. N. Kambesis and J. E. Mylroie. 2016. Sistema Faro, Isla de Mona, Puerto Rico: speleogenesis of the world's largest flank margin cave. Boletín Geológico y Minero 127(1):205217.

Martínez, M. I., J. W. Troester and R. T. Richards. 1995. Electromagnetic surface geophysical exploration of the ground-water resources of Isla de Mona, Puerto Rico: A Caribbean carbonate island. Carbonates and Evaporites 10(2): 184-192.

Mylroie, J. R. and J. E. Mylroie. 2007. Development of the carbonate island karst model. Journal of Caves and Karst Studies 69(1):59-75.

Nieves, V. M. 2010. Mona: Una Leyenda entre el Mar y el Sol. Impressive Publications. San Juan, Puerto Rico. 224 pp.

Nieves-Rivera, Á. M. 2012. Comentarios acerca de las cuevas de Isla de Mona. EspeleoRevista Puerto Rico 6:1-4. [January-June]

Nieves-Rivera, Á. M. 2019. Los fósiles en las cuevas de Isla de Mona. Revista Educativa Cultural Guácara 7(1):17-18. [July-December]

Nieves-Rivera, Á. M. and D. A. McFarlane. 2001. In search of the extinct hutia in cave deposits of Isla de Mona. National Speleological Society News 59(4):92-95. [April]

Nieves-Rivera, Á. M. and E. H. Williams. 2003. Annual migrations and spawning of Coenobita clypeatus (Herbst) on Mona Island (Puerto Rico) and notes on inland crustaceans. Crustaceana 76(5):547-558. https://doi.org/10.1163/156854003322316191

Nieves-Rivera, Á. M., J. E. Mylroie, and D. A. McFarlane. 1995. Puffinus lherminieri and two other vertebrates from Isla de Mona. National Speleological Society Bulletin 57:99-102.

Olson, S. L. 2015. History, morphology, and fossil record of the extinct Puerto Rican parakeet Psittacara maugei Souancé. The Wilson Journal of Ornithology 127(1):1-12. https://doi.org/10.1676/14-020.1

Olson, S. L. 2018. A new species of large, terrestrial caracara from Holocene deposits in southern Jamaica (Aves: Falconidae). Journal of Raptor Research 4(2):265-272. https://doi.org/10.3356/JRR-08-18.1 
Olson, S. L. and Á. M. Nieves-Rivera. 2010. Fossil evidence and probable extinction of the greater fishing bat Noctilio leporinus (Chiroptera: Noctilionidae) on Isla de Mona, Puerto Rico. Mastozoologia Neotropical 17(1):167-170.

Panuska, B. C., J. M. Mylroie, D. Armentrout, and D. McFarlane. 1998. Magnetostratigraphy of Cueva del Alemán, Isla de Mona, Puerto Rico and the species duration of Audubon's shearwater. Journal of Caves and Karst Studies 60(2):96-100.

Peck, S. B. and J. Kukalova-Peck. 1981. The subterranean fauna and conservation of Mona Island (Puerto Rico): a Caribbean karst environment. National Speleological Society Bulletin 43(3):5968.

Pérez-Reyes, O., T. O. Crowl, P. J. Hernández-García, R. Ledesma-Fusté, F. A. Villar-Fornes, and A. P. Covich. 2013. Freshwater and decapods of Puerto Rico: A checklist and reports of new localities. Zootaxa 3717(3):329-344. https://doi.org/10.11646/zootaxa.3717.3.3

Pérez-Rivera, R. A. and G. Bonilla. 1983. Nuevos informes y comentarios sobre aves de la Isla de Mona. Science-Ciencia. Boletín Científico del Sur (Ponce, Puerto Rico) 10(3):97-101.

Quinlan, J. F. 1974. Preliminary exploration and evaluation of the caves of Mona Island, including a description of origin. U.S. National Parks Service. Unpublished administrative report. Copy in the U.S. Geological Survey Center. Guaynabo, Puerto Rico. 33 pp.

Richards, R. T., J. W. Troester and M. I. Martínez. 1998. An electromagnetic geophysical survey of the freshwater lens of Isla de Mona, Puerto Rico. Journal of Caves and Karst Studies 60(2): 115120.

Rodríguez Delgado, A. M., L. González and W. Ramírez Martínez. 2012. Las rocas de las cuevas de Isla de Mona. EspeleoRevista Puerto Rico 7: 17-23.

Rodríguez-Durán, A. and E. Padilla-Rodríguez. 2010. New records for the bat fauna of Mona Island, Puerto Rico, with notes on their natural history. Caribbean Journal of Science 46(1):102-105. https://doi.org/10.18475/cjos.v46i1.a13

Rodríguez-Durán, A. and K. Christenson. 2012. Breviario sobre los murciélagos de Puerto Rico, La Española e Islas Virgenes. Published by Universidad Interamericana de Puerto Rico, Bayamón, Puerto Rico. 104 pp.

Rolle, F. J. 1961. The avifauna of Mona Island, Puerto Rico. Florida Naturalist 34(4):195-202.

Rovere, A., M. E. Raymo, M. Vacchi, T. Lorscheid, P. Stocchi, L. Gómez-Pujol, D. L. Harris, E. Casella, M. J. O'Leary, and P. J. Hearty. 2016. The analysis of the Last Interglacial (MIS 5e) relative sea-level indicators: Reconstructing sea-level in a warmer world. Earth-Science Reviews 159:404-427. https://doi.org/10.1016/j.earscirev.2016.06.006

Sampson, A. V. M. and J. Cooper. 2015. History on Mona Island: Long-term human and landscape dynamics of an "uninhabited" island. New West Indian Guide 89:30-60. https://doi.org/10.1163/22134360-08901054

Schmoll, B. S., J. L. Carew, and J. E. Mylroie. 1999. Petrologic analysis of Cueva de Agua, Punta Los Ingleses, Isla de Mona, Puerto Rico. pp. 110-115. In, H. A. Curran and J. E. Mylroie (Editors). Proceedings of the 9th Symposium on the Geology of the Bahamas and Other Carbonate Regions. Bahamian Field Station, Ltd., San Salvador, Bahamas. 142 pp.

Smith, D. G. and A. M. Wier. 1999. On some inland Crustacea and their habitats of Mona Island in the northern Caribbean region. Crustaceana 72(7):635-646. https://oi.org/10.1163/ 156854099503681

Wadsworth, F. H. 1977. Reseña histórica de la Isla de Mona. Revista/Review Interamericana 6(4):587621.

Wadsworth, F. H. 2003. Guía para la Isla de Mona. Contribución del Comité de Campamentos, Concilio de Puerto Rico, Boy Scouts of America. First Publishing of Puerto Rico. Guaynabo, Puerto Rico. 119 pp.

Wicks, C. M. and J. W. Troester. 1998. Groundwater geochemistry of Isla de Mona, Puerto Rico. Journal of Cave and Karst Studies 60(2):107-114.

Williams, E. E. 1952. A new fossil tortoise from Mona Island, West Indies and a tentative arrangement of the tortoises of the world. Bulletin American Museum of Natural History 99(9):547-561.

Zegarra Vila, J. P. 2013. Galería subterránea: Cueva del Agua. EspeleoRevista Puerto Rico 8:38-51 [https://issuu.com/espeleorevista/docs/espeleorevista_8]. 